\title{
A Trial to Reproduce an Ancient Iron-making Process in Chiba Prefecture
}

\section{The late Naoki YAMAGUCHI, Yoshinori ANAZAWA, ") Mitsuru TATE ${ }^{2)}$ and Minoru SASABE ${ }^{3)}$}

Formerly Chiba Prefectural Boso-Fudoki-no-Oka Museum.

1) Boso-Fudoki-no-Oka Museum, Sakai-machi, Inba-gun, Chiba-ken, 270-15 Japan.

2) Professor Emeritus, The University of Tokyo.

3) Chiba Institute of Technology, Tsudanuma, Narashino, Chiba-ken, 275 Japan.

(Received on August 14, 1996; accepted in final form on November 12, 1996)

A trial to reproduce an ancient iron-making process were carried out by the Boso-Fudoki-no-Oka Museum. An object of the article is an introduction to operation data and the results of the trial. Seven times trials were carried out.

$3.3 \mathrm{~kg}$ of iron lump could be obtained by using $33 \mathrm{~kg}$ of iron sand and $61 \mathrm{~kg}$ of charcoal.

KEY WORDS: ancient iron making; reproduce smelting; furnace; refractory; iron sand.

\section{Introduction}

About 25 years ago, the prefectural government of Chiba named a hilly district located near Narita where there are many of ancient mounds built in the 6 th to the 7th century, "Fudoki-no-Oka". "Fudoki" in Japanese is the name of a series of prefectural topographies edited officially and published by the order of the Japanese Court in the 8th century. "Oka" in Japanese means a hill. In the district, ancient iron-making sites are also found. An archaeological museum, Chiba Prefectural BosoFudoki-no-Oka Museum, was set up in the district by Chiba prefectural government in 1978 with the purposes of protecting ancient culture and promoting archaeological investigation and education.

Since then the museum has delivered archaeological lectures to citizens every year. The lectures included iron-making experiments ranging from iron-sand smelting to steel knife smithing in order to give them the chance to learn how to make iron through their own

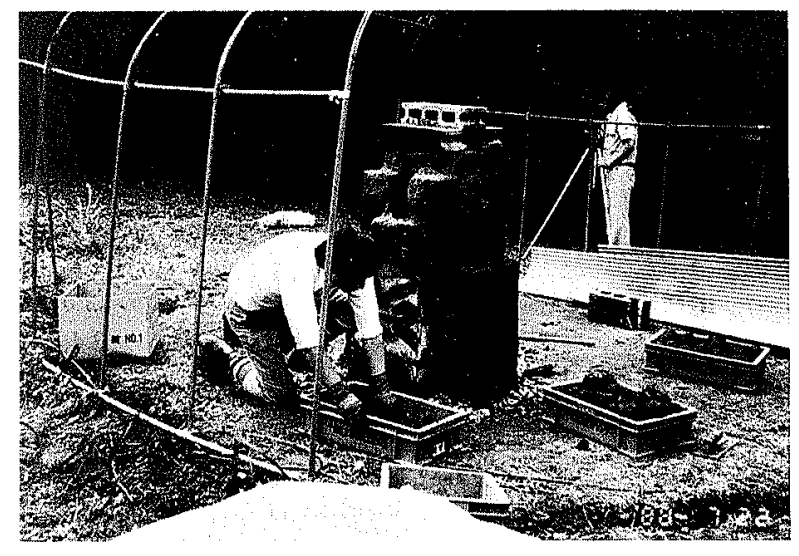

Fig. 1. External appearance of the furnace under construction. experience and to find approaches to the reproduction of the ancient iron-making process of the district.

In the course of lectures given from 1988 till 1991, seven trials with a reconstructed experimental iron smelting furnace were conducted. Figures 1 and $\mathbf{2}$ show the external appearance of the furnace under construction and a woman citizen engaging in sieving work, respectively. The results of the campaigns were reported in Japanese in the three volumes of the Annual Report of the Museum, ${ }^{1-3)}$ published in 1991-1993. This article is a modification of the abridged English translation of these three reports by the late professor $Z$. Hara. These reports have been not yet published.

\section{Construction of the Experimental Smelting Furnace}

\subsection{Prototype and Scale Ratio}

The shaft type smelting furnace used in the experiment has a reduced scale of the No. 37 ancient furnace excavated at Hanamae-site, Kashiwa city in Chiba pre-

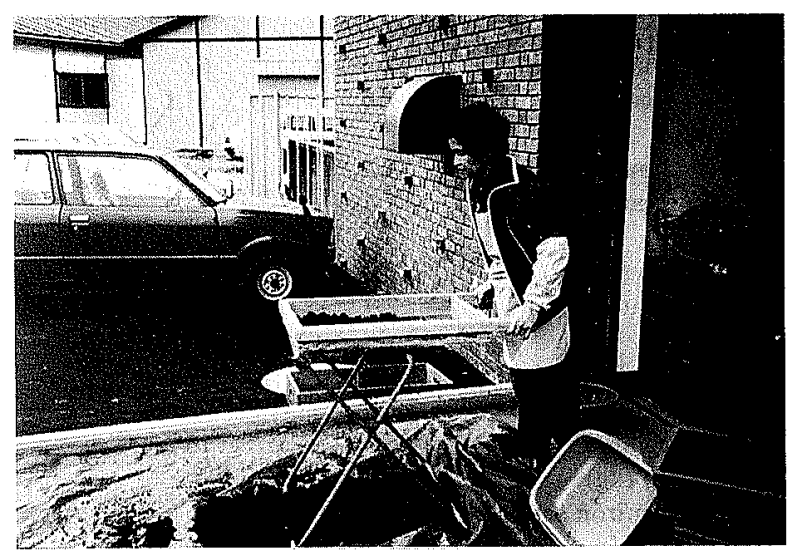

Fig. 2. A citizen sieving soil for the furnace wall lining material. 
fecture, whose approximate dimensions were as follows: the inner diameter of the hearth $-600 \mathrm{~mm}$, the height from hearth bottom to floor for bellow-working $-1000 \mathrm{~mm}$ : the inner diameter of the upper tuyere $-90 \mathrm{~mm}$. Although the scale ratio of the furnace to model one was about $1 / 2$, its profile was changed with every campaign in order to improve smelting conditions. Figure 3 shows the crosssectional view of the furnace used in the 3rd campaign.

\subsection{Dimensions and Profile}

The dimensions of the furnaces together with several operational data from each campaign are shown in Table

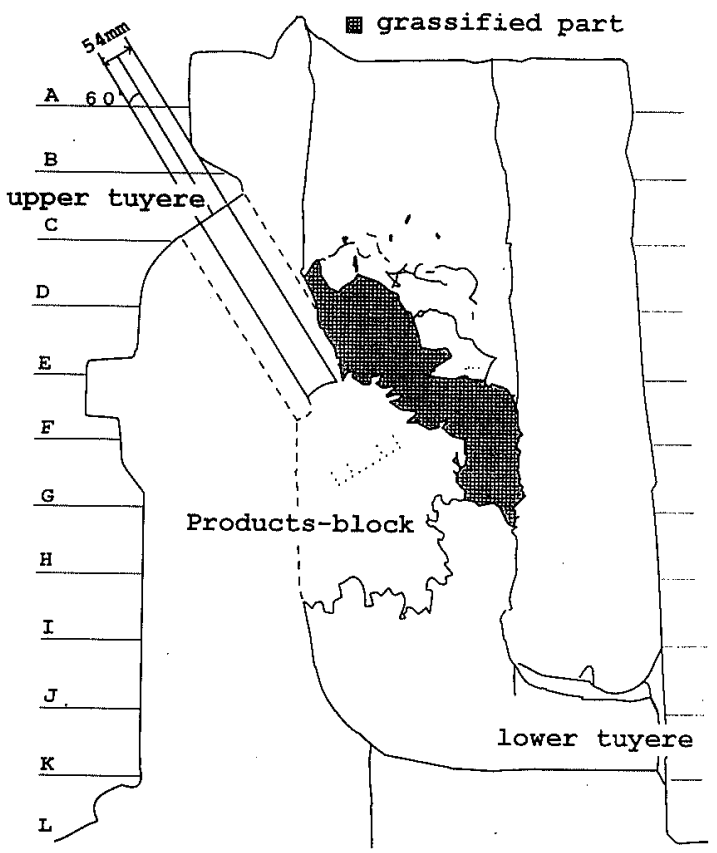

Fig. 3. Cross sectional view of the furnace used in the 3rd campaign.
1. The hearth bottom in the 1st campaign was placed under ground level. It was slightly raised up, but still located underground in the 2nd campaign. After the $3 \mathrm{rd}$ campaign it was located at ground level. The upper tuyere was installed with an angle of $60^{\circ}$ inclination to the horizon so that its nose was located $300-400 \mathrm{~mm}$ above the lower tuyere in the early campaigns. After the 4th campaign the upper tuyere was inserted more deeply into the furnace and the position of its nose was lowered; at the same time its inner diameter was enlarged. The lower tuyere, which, in practice, was used not for blasting but for slag tapping in all campaigns, was a hole bored horizontally through the hearth wall at the various distances from the bottom level. Hereafter the upper tuyere is called simply "tuyere" and the lower one "slag notch."

\subsection{Refractory Materials for the Wall Lining and Tuyere Making}

It is known that the walls of the excavated ancient furnace were made from a mixture of black-soil, sand, Kanto loam or clay and shredded straw which acted as fiber for plastering. On the basis of this knowledge, a mixture of 5 parts soil with 5 parts sand containing $100 \mathrm{~g}$ shredded straw per $10 \mathrm{~kg}$ was used as the wall lining material for experimental furnaces. The sand had been collected from the Narita-formation. The soil containing humic material had been collected from a shallow wastefilled valley located near the museum.

\subsection{Construction of Furnace}

A flat area in the forest surrounding the museum was chosen as the furnace site. A pit of $1 \mathrm{~m}$ in diameter and $0.65 \mathrm{~m}$ in depth was dug out. Bundles of wood were burned in the pit till its wall reached red-heat. Then sand

Table 1. Dimensions of furnace and some operation data.

\begin{tabular}{|c|c|c|c|c|c|c|c|}
\hline & $\begin{array}{l}\text { 1st Campaign } \\
\text { Feb. } 13,1988\end{array}$ & $\begin{array}{l}\text { 2nd Campaign } \\
\text { Jul. } 23,1988\end{array}$ & $\begin{array}{l}\text { 3rd Campaign } \\
\text { Dec. } 15,1988\end{array}$ & $\begin{array}{c}\text { 4th Campaign } \\
\text { Jan. } 28,1990\end{array}$ & $\begin{array}{c}\text { 5th Campaign } \\
\text { Jan. } 13,1991\end{array}$ & $\begin{array}{l}\text { 6th Campaign } \\
\text { Aug. } 13,1991\end{array}$ & $\begin{array}{l}\text { 7th Campaign } \\
\text { Oct. } 27,1991\end{array}$ \\
\hline \multicolumn{8}{|l|}{ Furnace } \\
\hline Height $\mathrm{A}(\mathrm{mm})^{1)}$ & 1517 & 1154 & 1060 & & 1053 & 1053 & 1053 \\
\hline Height $B(\mathrm{~mm})^{2)}$ & 1183 & 988 & 1060 & & 1050 & 1050 & 1050 \\
\hline \multicolumn{8}{|l|}{ Hearth } \\
\hline Inner diameter $(\mathrm{mm})$ & $256-254$ & $302-332$ & $314-312$ & & $350-310$ & $350-360$ & $360-340$ \\
\hline \multicolumn{8}{|l|}{ Tuyere } \\
\hline Height (mm) & 310 & 304 & 440 & & 183 & & 235 \\
\hline Inner diameter $(\mathrm{mm})$ & 42 & 41 & 54 & 65 & 65 & 84 & 68 \\
\hline Inclining angle (deg) & 57 & 62 & 60 & 60 & 64.5 & 60 & 64 \\
\hline Smelting time $(\mathrm{hr})$ & 4.6 & 7.1 & 6.7 & 6.8 & 6.2 & 11.9 & 9.8 \\
\hline \multicolumn{8}{|l|}{ Charcoal } \\
\hline Total amount (kg) & 34.2 & 40.8 & 39.6 & 43.6 & 41.7 & 61.0 & 50.7 \\
\hline Chaging rate $(\mathrm{kg} / \mathrm{h})$ & 7.4 & 5.5 & 5.9 & 6.4 & 6.7 & 5.1 & 5.1 \\
\hline \multicolumn{8}{|l|}{ Iron sand } \\
\hline Total amount $(\mathrm{kg})$ & 12.6 & 19.4 & 20.4 & 21.0 & 14.6 & 33.0 & 21.2 \\
\hline Chaging rate $(\mathrm{kg} / \mathrm{h})$ & 2.7 & 2.6 & 3.0 & 3.1 & 2.4 & 2.8 & 2.2 \\
\hline \multicolumn{8}{|l|}{ Burden ratio } \\
\hline Charcoal/iron sand & 2.7 & 2.1 & 1.9 & 2.0 & 2.0 & 1.8 & 2.4 \\
\hline \multicolumn{8}{|l|}{ Product } \\
\hline Total weight $(\mathrm{kg})$ & 6.3 & 15 & & 11.2 & 13.8 & 19.9 & 15.0 \\
\hline Iron lump $(\mathrm{kg})$ & & & & 6.0 & 3.9 & 3.3 & 2.6 \\
\hline Yield (iron/iron sand) & & & & 0.28 & 0.27 & 0.10 & 0.12 \\
\hline
\end{tabular}

1) From the top of the shaft to the hearth bottom.

2) From the top of the shaft to the slag notch. 


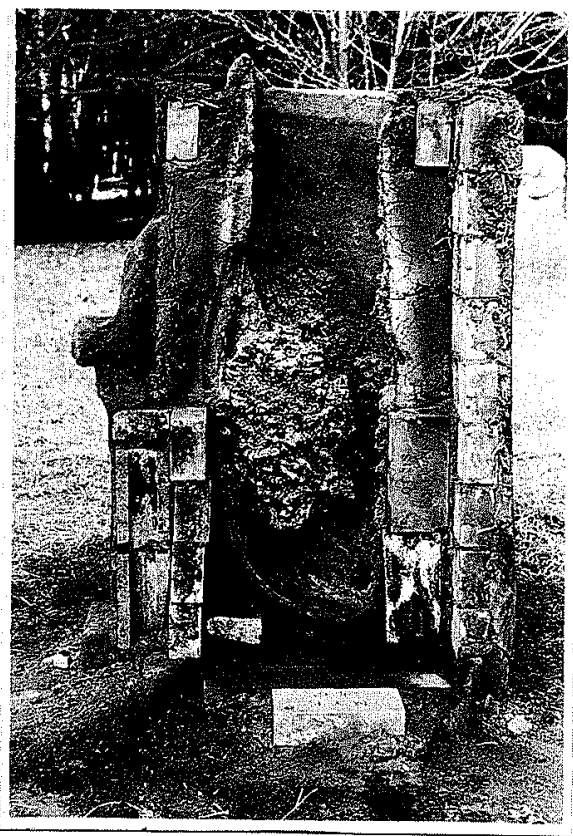

Fig. 4. Inside view of dismantled furnace after the $3 \mathrm{rd}$ campaign.

was laid on the bottom of the pit, on which concrete blocks were piled up to near the ground level.

The furnace was constructed on these blocks. The bottom of hearth was made from the wall-lining material mentioned above. To save time, the furnace wall was constructed by sandwiching refractory fire bricks with the lining material as shown in Fig. 4. The refractory index of the fire brick was SK32; that is, it should stand against high temperature of up to $1300^{\circ} \mathrm{C}$. For the 1st furnace only the wall of the upper shaft was constructed with a welded steel plate pipe with no use of lining material

\subsection{Tuyere}

The tuyere was made from mixtures of clay, sand, black-soil and Kanto-loam. The mixing ratio of these materials was changed as follows: $6: 3: 1: 0$ in the 1 st to 4th campaigns; $2: 4: 2: 2$ in the 5th campaign; $5: 3: 0: 3$ in the 6 th and 7 th campaigns. The tuyere was connected to a blower. The inner surface of hearth wall facing the tuyere nose was slightly concave as in the ancient furnace.

\subsection{Drying}

After the make-up of the furnace several bundles of wood were piled up and burnt around the furnace in order to dry the furnace wall. Due to the tight schedule of the experiments, such a rapid drying operation had to be carried out in every campaign.

\section{Operation}

\subsection{Raw Material and Fuel}

Iron sand collected at a beach in Asahi-city, Chiba prefecture along the Pacific Ocean was washed and separated from light admixtures in a dressing pan in flowing fresh water. The yield of the heavy sand thus obtained was 97 mass $\%$. It was dried and then divided into $500 \mathrm{~g}$ measures and stored in bags made of polyvinyl chloride. Charcoal made from a kind of oak wood was

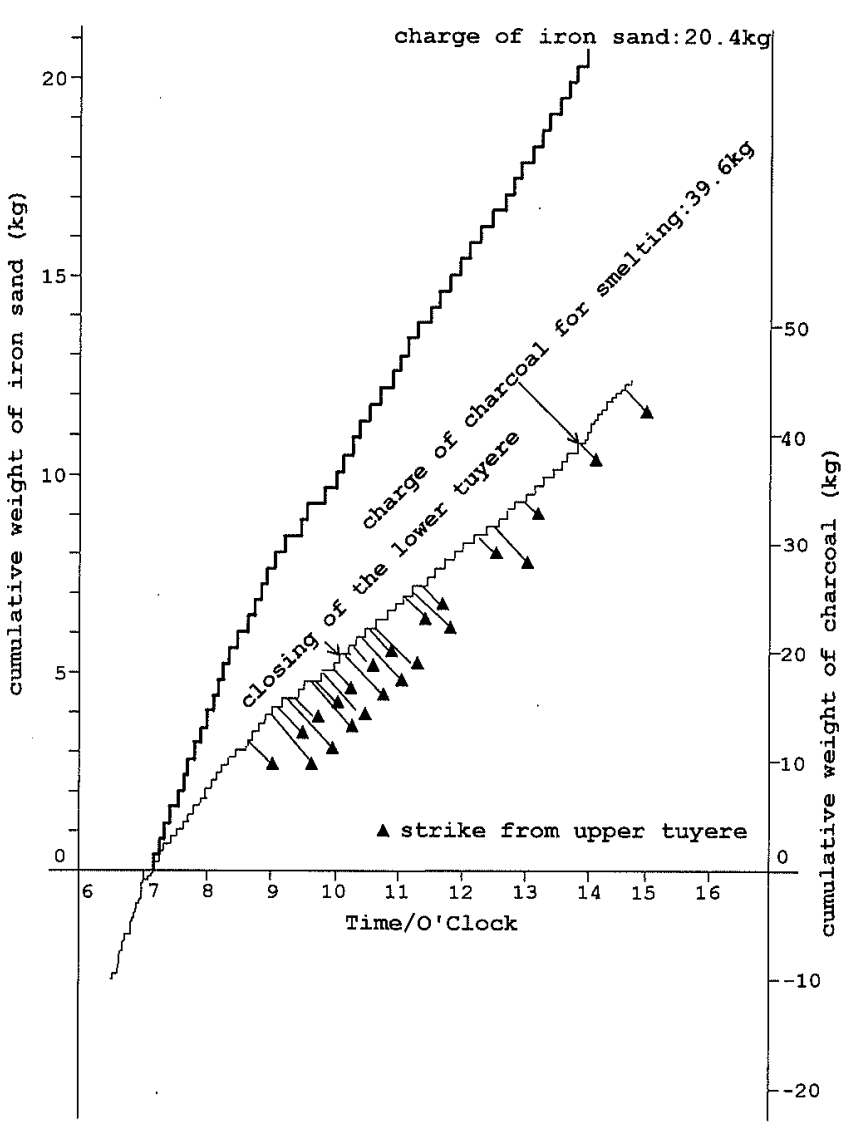

Fig. 5. Progress of smelting operation in the 3rd campaign.

sized in the range of 40 to $50 \mathrm{~mm}$. The chemical analysis of the iron sand together with those of the furnace wall, tuyere and slag are shown in Table $2 .^{43}$

\subsection{Progress of Operation}

Usually each campaign started up at six or seven o'clock in the morning and continued in about $9 \mathrm{~h}$. At the beginning of the operation, charcoal alone was charged into the furnace for about $2 \mathrm{~h}$ in order to preheat the furnace. At the end of this preheating period, it was observed through the tuyere that its nose had begun to melt. Then $500 \mathrm{~g}$ of heavy sand and $1 \mathrm{~kg}$ of charcoal were alternately charged. An air blast was continuously supplied through the tuyere by a blower driven by a $500 \mathrm{~kW}$ electric-motor.

An example of progress of an operation is shown in Fig. 5. Along with the progress of the operation, some obstructive phenomena occurred at the tuyere nose in the following way. A part of the furnace wall above the tuyere nose began to melt and the inner diameter of the tuyere decreased because of the temporary adhesion of the resultant molten material: however the molten material soon fell off under its own weight and the initial inner diameter was restored. Subsequently the tuyere nose itself began to melt down and the inner diameter decreased gradually with the adherence of the molten material, causing a decrease in blast volume. Finally molten slag, which could not flow down, rose up to the tuyere, clogged it, and made operation impossible. In such a situation the tuyere was opened by inserting a steel rod through the tuyere and pushing down the blast-obstructive materials into the furnace. Slag which 
Table 2. Chemical analysis (mass\%) of iron sand, furnace wall,* tuyere,* and slag.*

\begin{tabular}{|c|c|c|c|c|c|c|c|c|c|c|c|c|}
\hline Name & T.Fe & M.Fe & $\mathrm{FeO}$ & $\mathrm{Fe}_{2} \mathrm{O}_{3}$ & $\mathrm{SiO}_{2}$ & $\mathrm{Al}_{2} \mathrm{O}_{3}$ & $\mathrm{CaO}$ & $\mathrm{MgO}$ & $\mathrm{K}_{2} \mathrm{O}$ & $\mathrm{Na}_{2} \mathrm{O}$ & $\mathrm{MnO}$ & $\mathrm{TiO}_{2}$ \\
\hline Iron sand & 58.3 & - & 28.6 & 51.6 & 2.36 & 2.12 & 0.28 & 2.12 & - & - & 0.45 & 10.95 \\
\hline Furn. wall & 5.86 & 0.12 & 2.91 & 5.38 & 60.15 & 1.53 & 1.44 & 1.53 & 1.56 & 1.52 & 0.47 & 0.73 \\
\hline Tuyere & 5.58 & 0.13 & 1.15 & 6.54 & 65.64 & 1.54 & 1.27 & 1.54 & 1.41 & 1.52 & 0.10 & 0.83 \\
\hline Slag & 8.51 & 5.09 & 2.66 & 1.94 & 28.57 & 6.77 & 19.33 & 6.77 & 1.67 & 0.64 & 1.01 & 19.25 \\
\hline
\end{tabular}

* Sampled from the furnace after the 5 th campaign.

adhered to the rod on these ocassions was used as samples for analysis. Triangle marks in Fig. 5 show the opening operations.

\subsection{Improvement of Operating Conditions}

From the 1 st to the 4 th campaigns, the slag notch i.e., lower tuyere was kept open during the operation so that condition in the furnace could be observed. Since this measure seemed to cool the hearth, however, it was closed completely after the 5 th campaign. In addition to that, the thickness of the hearth wall was increased by using concrete blocks in the 6 th and 7 th campaign. The use of blocks seemed to contribute to an increase in hearth temperature.

The 1st campaign had to be stopped halfway because of time limit of the lecture. From the 2nd to the 5th campaigns, the smelting operations had to be stopped because of the clogging of the tuyere.

In the smelting operations from the 1 st to the 4 th campaigns, slag did not flow out through the slag notch because of its lower fluidity. It was estimated on the basis of the above mentioned phenomena that the hearth temperature was too low to keep the slag fluid. In the 6 th and the 7 th campaigns slag flew out through the slag notch and the formation area of small iron lumps was extended toward the hearth bottom.

At the end of each campaign the furnace was cut vertically into two parts. Contents in the vertical half of the furnace were dismantled layer by layer in order to observe a distribution of burden and products.

\section{Products}

\subsection{Ist Campaign}

A large block of product was found in the hearth. The products was probable produced near the tuyere nose during the operation. The block was cut by a steel saw vertical and horizontal sections in order to observe inside the block. The products in the vertical section were distinguished into three parts. The lowest one consisted of molten slag and charcoal pieces of 5 to $30 \mathrm{~mm}$ in size covered with thin film of reduced iron. It was estimated that the slag could not keep its molten state in the hearth due to lower temperature as well as that the thin metallic film might be produced by the direct reduction of iron sand particles stayed on the charcoal surface.

The middle part of the block consisted of metallic iron lumps aggregated like bunches of grapes and of charcoal particles of about $10 \mathrm{~mm}$ in size as well as porous filmy slag among the bunches. It is estimated that the iron lumps were reduced in front of the tuyere nose. The upper part of the block was composed of porous slag

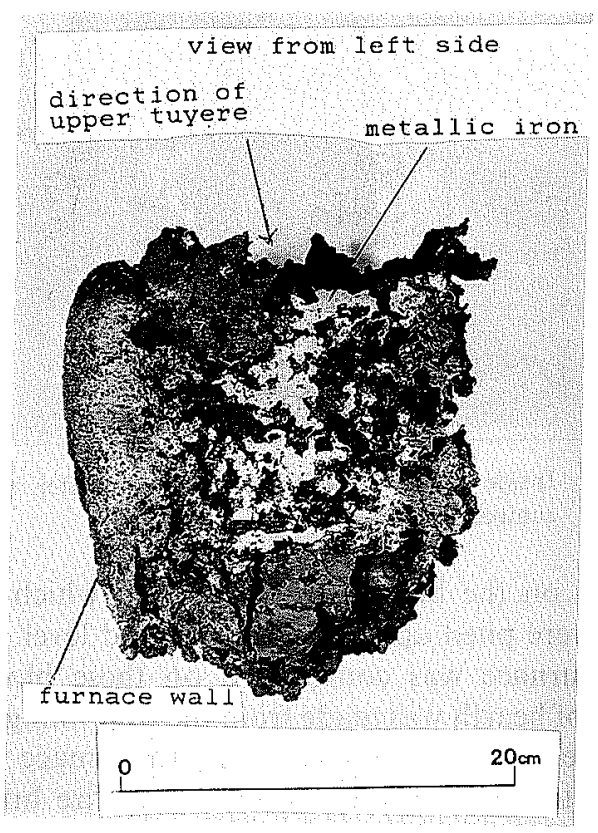

Fig. 6. Cross-sectional view of products-block obtained in the 2nd campaign.

mingled with charcoal pieces and iron sand not yet reduced. The change of the color of inner wall surface suggested that the high temperature area was very narrow in the 1st campaign.

\subsection{2nd Campaign}

A block of products is larger than that of the 1st campaign, was found in front of the tuyere nose. Five parts were discriminated in the vertical section: two sides and three central layers. Three-dimensionally the central layers were surrounded by the curved wall-like substances around their two sides, as shown in Fig. 6.

The lower layer which was constituted of almost molten slag was denser than that of the 1st campaign. The middle layer was composed of small metallic iron lumps. It was estimated that the lumps were produced by the formation of metallic iron particles near the tuyere nose and their aggregation or growth with the receding of the tuyere due to melting-down of its nose. The upper layer constituted of slag originating in the fusion of the wall lining and tuyere. The side part on the opposite side of the tuyere consisted of a mixture of porous molten slag with charcoal pieces, small iron particles and filmy iron. The other side part facing the tuyere was composed of same material as wall lining.

\subsection{3rd Campaign}

The shallower hearth due to raising the bottom in the 3rd furnace caused some increase of hearth temperature. 


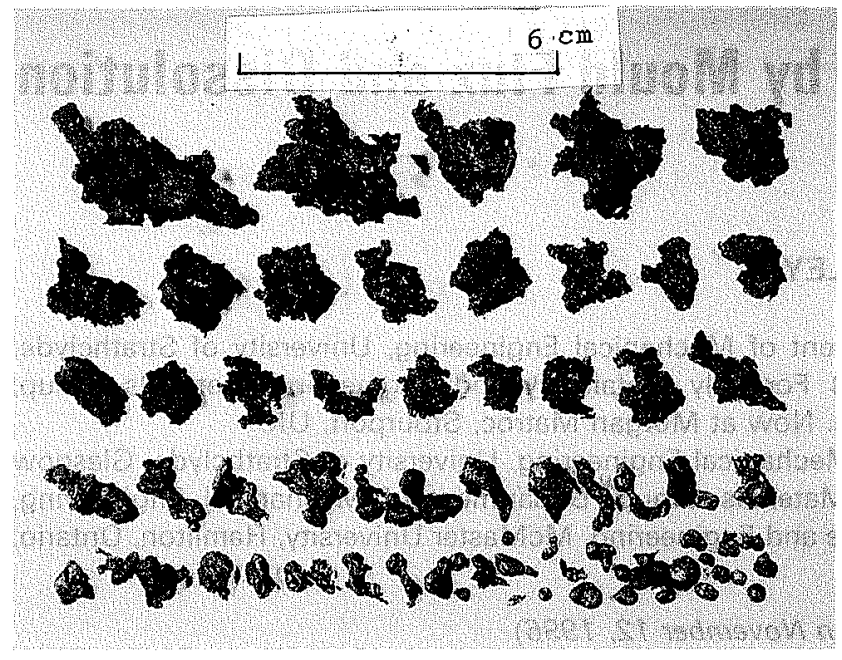

Fig. 7. Small iron lumps from the product of the 5th campaign.

In accordance with this, slag constituting the lower part of the products block seemed to be more fluid than those of previous operations. The slag, however, were not yet so fluid as able to flow out of the slag notch. The half block shown in Fig. 6 is preserved as an exhibition of the museum.

\subsection{4th Campaign}

The tuyere was inserted more deeply into the furnace than previous operations accompanying the following changes. The products block was larger and more porous and it contained more metallic iron lumps. But the bottom of the block still did not reached hearth bottom.

\subsection{5th Campaign}

The tuyere was inserted still more deeply into the furnace and the slag notch was closed. As a result of these measures, a large block of products was obtained, which was broken into two parts while taking it out. The upper half of the block consisted of some aggregates of iron lumps as shown in the upper three lines of Fig. 7. The largest of them weighed about $800 \mathrm{~g}$. The other half was composed of slag, charcoal pieces and small iron particles, whose drop-like appearance, shown in the lower two lines of Fig. 7, suggested their molten state during the operation.

\subsection{6th and 7th Campaign}

The enlargement of the inner diameter of the tuyere and the increase of the thickness of hearth wall caused a remarkable increase of hearth temperature. When the slag notch was open at the end of the 6th campaign, molten slag flew out through the notch for the first time.
Table 3. Chemical composition (mass\%) of small iron lumps in the 5th campaign.

\begin{tabular}{cccccccc}
\hline Location of sample & $\mathrm{C}$ & $\mathrm{Mn}$ & $\mathrm{P}$ & $\mathrm{S}$ & $\mathrm{Cu}$ & $\mathrm{Ti}$ & $\mathrm{V}$ \\
\hline Upper part & 0.78 & 0.05 & 0.067 & 0.02 & 0.010 & 0.33 & 0.023 \\
Lower part & 2.83 & 0.02 & 0.172 & 0.02 & 0.015 & 0.090 & 0.057 \\
\hline
\end{tabular}

However the iron product yield was very low as shown in Table 1. An insufficient charcoal charge was believed to be the cause.

\section{Chemical Composition of the Small Iron Lumps}

Chemical analysis of the small iron lumps in the 5th campaign are shown in Table 3. ${ }^{4)}$ The sample from the upper part showed a martensitic structure corresponding to its carbon content. Its high titanium content may originate in the slag film which covered the sample taken out of the furnace. In this connection it should be noticed that the slag in the 5th campaign, whose $\mathrm{TiO}_{2}$ content was $19.25 \%$ as shown in Table 2, consisted of a glassy material containing pseudobrookite in the dispersed state.

The sample from the lower part showed the structure of gray cast iron containing flaky carbon, suggesting a higher temperature at its location. The higher phosphorus content should be considered the natural result of this condition.

\section{Summary}

Recently many ancient iron-making furnaces have been excavated in Chiba prefecture and near them a great quantity of crushed slag small quantity of small iron lumps have been found. The shapes of these lumps are quite similar to those of the lumps obtained in the experiments stated above. On the basis of this fact and of the comparison of the chemical composition of iron lumps produced in the experiments with that of ancient ones, it is considered that the experiments could be an approach to the reproduction of the ancient iron-making process in this district.

\section{REFERENCES}

1) N. Yamaguchi: Annual Report of Chiba Prefectural BosoFudoki-no-Oka Museum, 14 (1991), 114.

2) N. Yamaguchi: Annual Report of Chiba Prefectural BosoFudoki-no-Oka Museum, 15 (1992) 52.

3) M. Ohsawa: Annual Report of Chiba Prefectural Boso-Fudokino-Oka Museum, 15 (1992), 124.

4) M. Ohsawa: Annual Report of Chiba Prefectural Boso-Fudokino-Oka Museum, 16 (1993), 29. 